\title{
Microbial Retting of Banana Pseudostem
}

\author{
Sonia Sharma, Neeraj Wadhwa
}

\begin{abstract}
Fibrous wastes correspond to approximately 54.3 wt.-\% of a banana plant. The waste weight is mainly of bunches, stems, and leaves. These ligno-cellulosic fibre waste can be designed and tailored to yield value added products which can be exploited by the farmers, exporters and weavers. Pectin (plant cement) and hemicelluloses (22-25\%) found in plant cell walls in the plate (middle lamella). These macromolecules have needs to be hydrolyzed faster without affecting the quality of fibre. The chemical and mechanical processes adopted for fibres actually affect color uptake, strength of fibre thus fetching lower price. We report a biological ecofriendly method of retting where pectinases produced by the endophytic microorganisms of banana pseudostem were used to separate the fibre bundles of cellulose.. Endophytes are microorganisms which live in close relationship with living plant tissues in a cooperative relationship delivering a few auxiliary metabolites and proteins with the possibility to hydrolyse a few plant-determined macromolecules of the host. They spend the entire or part of their lifecycle colonizing within sound tissues of the host plants.The endophytic pectinase helps to break down the cell walls and can find commercial application in extraction of fibres.Seven bacterial isolates were screened and isolated in pectinase screening agar medium [PSAM]. Pectinase producing endophytic bacteria is isolated from corm of Amorphophallus paeoniifolius reported by us are Staphylococcus sciuri, Exiguobacterium acetylicum, Exiguobacterium indicum which are good pectinase producers having specific activity of 8.26, 12.61, 6.81 respectively. Treatment of banana pseudostem with these microbes showed $91 \%, 94 \%, 96.7 \%$ loss in the total weight of stem leaving behind pure cellulose fibres.
\end{abstract}

Keywords: Banana pseudostem, Endophytes, Pectinase, Cellulose fibres, 16s RNA, Retting

\section{INTRODUCTION}

$\mathrm{R}$ Retting process of plant material involves mechanical, chemical and/or enzymatic reactions. Ecofriendly retting processes utilize complex microbial community for accelerating the release of soluble constituents like sugar, glycosides and nitrogenous compounds from complex polymers of the plant material from where the cellulose fibres need to be extracted. This processes of release of simple monomers also helps in further growth of microbes. Biofibres are natural polymers, they are generally biodegradable but they do not possess the necessary thermal and mechanical properties desirable for engineering plastics. Literature also shows some reviews on cellulosic as well as

Manuscript received on October 06, 2021.

Revised Manuscript received on October 12, 2021.

Manuscript published on October 30, 2021.

* Correspondence Author

Sonia Sharma, Ph.D Scholar, Department of Biotechnology, Jaypee Institute of Information Technology (Uttar Pradesh), India.

Prof. Neeraj Wadhwa*, Professor, Department of Biotechnology, Jaypee Institute of Information Technology (Uttar Pradesh), India.

(c) The Authors. Published by Blue Eyes Intelligence Engineering and Sciences Publication (BEIESP). This is an open access article under the CC BY-NC-ND license (http://creativecommons.org/licenses/by-nc-nd/4.0/) ligno-cellulosic fibre based composites. which can be tailor made to make versatile products like rugs, fabrics etc. Since bio-fibres are cheap and biodegradable, the bio composites from bio-fibre reinforced biodegradable polymers can render a major contribution in solving waste disposal which is serious environmental problem of 21st century [1] Vegetable and fruit plants waste are one of the main environmental problems that exist today and there is need for developing value added products from this waste which will benefit the farmers and the weavers. In the banana cultivation industry it is found that there is generation of high amount of organic waste in form of leaves, pseudo-stem .It is the fruit that is exported and this only represents $11.16 \mathrm{wt} . \mathrm{\%}$ of the plant total weight. All other waste residues correspond to fibrous and non-fibrous materials. Fibrous wastes corresponding to 54.3 wt.-\% of the total plant weight are mainly bunches, stems, and leaves. From all these parts of the plant, fibre bundles can be extracted. Different methods can be implemented to separate fibre bundles from vegetable resources like employing mechanical, chemical procedures alone or in combination. Both biological and chemical processes are traditionally employed to extract soft fibres such as flax and jute by retting procedures. Fermentation of vegetable source can be performed by anaerobic or aerobic ways, generating soluble components and gases such as methane. In general, this procedure consists in soaking a vegetable waste source for some days in water containing a concoction of microorganisms. Fibre bundles are thus obtained by the biological action of microorganisms present in the bath [2]. Retting is a fermentation process, where certain bacteria (e.g., Clostridium, Bacillus) and fungi (e.g., Aspergillus, Penicillium) release the fibre by decomposing pectin present in the bark[3]. Pectin and hemicelluloses (22-25\%) are the plant cement and are rich in the primary wall and middle lamella. The predominant task for extraction of fibre is to remove these non-cellulosic substances without causing damage to the fibre cellulose. Pectinases are the group of enzymes that helps to break down the cell walls cementing material. They have been utilized to increase the volume of fruit and vegetable juices, lowering the viscosity of the juice, reducing the cloudiness of the juice, caused by suspended pieces of cell wall [4].

\section{MATERIAL AND METHODS}

\section{A. Screening of pectinase producing bacteria}

Seven bacterial isolates from the corm were cultivated in pectinase screening agar medium [PSAM]. Nutrient agar containing $1.5 \%$ pure pectin. Media is sterilized by autoclaving at $121^{\circ} \mathrm{C}$ for $15 \mathrm{~min}$. bacteria were streaked on plates. pectin utilization was detected by flooding the culture plates with freshly prepared iodine-potassium iodide solution

Published By:

Blue Eyes Intelligence Engineering and Sciences Publication (BEIESP)

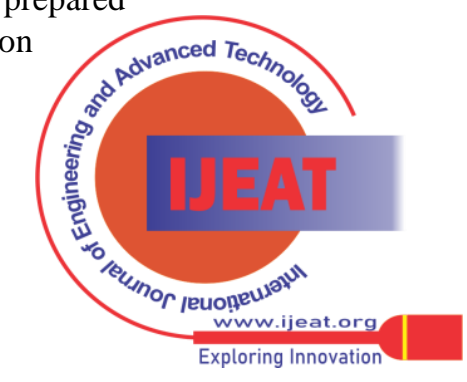




\section{Microbial Retting of Banana Pseudostem}

[Iodine-1.0 g, potassium iodide-5.0g in 330ml distilled water] this solution gives color to the medium containing pectin resulting in a translucent halo region where pectin is degraded, which indicated the presence of pectinolytic activity[5].

\section{B. Secondary screening of pectinase}

All pectinase producing endophytes were inoculated in media of composition peptone 3g, yeast extract-0.5g, KH2PO4-0.15g, $\mathrm{CaCl}_{2}-0.001 \mathrm{~g}$, pectin $-0.5 \mathrm{~g}, \mathrm{Na}_{2} \mathrm{CO}_{3}-0.5 \mathrm{~g}$ at $\mathrm{pH} 8[6]$.

\section{Identification of bacteria by using 16S rRNA}

All the seven endophytic bacteria were classified by $16 \mathrm{~S}$ rRNA identification. Sequencing was done by Sanger method in ABI 3500xL genetic analyzer (Life Technologies, USA) at NCIM Pune

\section{Determination of extracellular enzyme activity}

Determination of reducing sugars was done by (DNS) method, 1959 utilizing pectin as substrate. For enzyme assay, $5 \mathrm{ml}$ of freshly grown culture was taken and centrifuged at $10,000 \mathrm{rpm}$ for $5 \mathrm{~min}$. The culture broth was centrifuged at 10,000 rpm and was served as the source of the enzyme. In addition, substrate was prepared by mixing $0.5 \%(\mathrm{w} / \mathrm{v})$ citrus pectin in $0.1 \mathrm{M}$ of $\mathrm{pH} 7.5$ phosphate buffer. $900 \mu \mathrm{l}$ of substrate was added to two clean labeled test tubes; enzyme blank and test sample, $100 \mu \mathrm{l}$ of distilled water and crude enzyme was added to the respective test tubes Reaction was stopped by adding DNS reagent $(2 \mathrm{ml})$ to each test tube after 10 minutes of incubation at $50{ }^{\circ} \mathrm{C}$.. Test tubes were placed in a boiling water bath $\left(92^{\circ} \mathrm{C}\right)$ for 10 minutes so that color develops. Finally, the tubes were cooled and freshly prepared sodium potassium tartarate $(1 \mathrm{ml})$ was added.. Absorbance values were measured at 540nm using spectrophotometer (JENWAY 6300 UV/Vis). Enzyme activity was measured against enzyme blank. One enzyme unit was defined as the amount of enzyme that catalyzes $\mu$ mol of galacturonic acid per minute $(\mu$ molmin -1$)$ under the assay conditions [7].

\section{E. Determination of amount of protein}

The amount of protein produced was assayed by Bradford test. 100ul of sample was diluted with $900 \mu$ l of water and mixed with $2 \mathrm{ml}$ Bradford reagent. Absorbance was taken at 595nm using spectrophotometer (JENWAY 6300 UV/Vis) [8].

\section{F. Production of pectinase by submerged fermentation}

All pectinase producing endophytes were inoculated in $500 \mathrm{ml}$ Erlenmeyer flask having $250 \mathrm{ml}$ of production media comprising of composition peptone $3 \mathrm{~g}$, yeast extract-0.5g, KH2PO4-0.15g, CaCl2-0.001g, pectin -0.5g, Na2CO3-0.5g at $\mathrm{pH} 8$ with $1 \%(\mathrm{v} / \mathrm{v})$ inoculum (106 spores $/ \mathrm{ml})$ and incubated at $30^{\circ} \mathrm{C}$ under shaking condition (150 rpm) for 10days. The culture broth was centrifuged at 10,000 rpm for $30 \mathrm{~min}$ at $4^{\circ} \mathrm{C}$. The supernatant was used to evaluate enzyme activity and weight of remaining stem at different days of retting mentioned below.

\section{G. Retting of pseudo-stem}

Retting was performed in presence of bacterial strains producing extra cellular pectinase under two conditions

(i) Bacterial retting in media and (ii) Bacterial retting in water. Bacterial inoculum were added to specific media in bacterial retting while in water bacterial inoculum was added in water at the beginning of the process. Each $500 \mathrm{ml}$ Erlenmeyer flask was used to ret 2-3 stems of approximately the same weight. After retting, stems were washed in running water and placed to dry in a petridish at room temperature [9].

\section{H. Loss in weight}

There is also reduction in weight of fibre after 10 days of experiment. The reduction in weight was calculated by measuring the weight before and after retting.

The retting of banana stem again carried out using Staphylococcus scuiri. About $5 \mathrm{~cm}$ and $1 \mathrm{~cm}$ wide banana stem fibre sticks were incubated in presence and absence of EDTA $(0.01 \mathrm{M})$ composition of the reaction mixtures was as follows;

i Glycine $-\mathrm{NaOH}$ buffer $\mathrm{pH} 9.0$ (100 $\mathrm{ml}$ of $100 \mathrm{~mm})$ of Cultural broth supernatant (100ul) showing the presence of enzyme activity was added in both the sets and the reaction mixtures were incubated for 24 hrs at $37^{\circ} \mathrm{C}$ in water bath followed by vigorous shaking and washing with hot water $(10 \mathrm{ml})$ for 60 minutes. Water was drained off and the treated fibres were dried for $72 \mathrm{hr}$. and their dry weight was calculated. Heat inactivated supernatant was considered as control.

\section{RESULT}

\section{A. Screening of pectinase producing bacteria}

Out of seven endophytes three bacterial strains gave positive pectinase test. Degradation of substrate pectin was visible in form of clear halo zone around the bacterial colony.

\section{B. Secondary screening of pectinase and Production of enzyme in cultivation media}

Yeast extract lactose , Tryptone media at alkaine $\mathrm{pH}$ (8-10) was the optimal media composition and condition for Staphylococcus sciuri growth and pectinase production; Yeast extract, pectin and $\mathrm{KNO}_{3}$ media at alkaline $\mathrm{pH}(8-10)$ was preferred by Exiguobacterium acetylicum; Exiguobacterium indicum preferred pectin and $\mathrm{KNO}_{3}$ media at acidic pH 4 (Unpublished -lab data ). The above mentioned three cultures were grown in secondary screening media and specific activity for the enzyme was calculated please refer to TableI

Table- I: Comparative analysis of specific activities of pectinase producing bacteria confirming that Exguobacterium acetylicum being a good producer of pectinase

\begin{tabular}{|c|c|c|c|c|}
\hline S.no & Culture broth & $\begin{array}{c}\text { Total } \\
\text { enzyme } \\
(\mu \mathrm{mol} \\
\mathrm{ml}^{-1} \mathrm{~min}^{-1}\end{array}$ & $\begin{array}{c}\text { Total } \\
\text { protein } \\
\mathrm{mg} / \mathrm{ml}\end{array}$ & $\begin{array}{c}\text { Specific } \\
\text { Activity }(\mu \mathrm{mol} \\
\mathrm{min}^{-1} \mathrm{mg}^{-1}\end{array}$ \\
\hline 1 & $\begin{array}{c}\text { Staphylococcus } \\
\text { sciuri }\end{array}$ & 6.94 & 0.84 & 8.26 \\
\hline 2 & $\begin{array}{c}\text { Exiguobacterium } \\
\text { acetylicum }\end{array}$ & 4.16 & 0.33 & 12.61 \\
\hline 3 & $\begin{array}{c}\text { Exiguobacterium } \\
\text { indicum }\end{array}$ & 2.58 & 0.38 & 6.81 \\
\hline
\end{tabular}


The culture broth was centrifuged and in the cell free supernatant pectinase activity was measured .We report that Exiguobacterium acetylicum showed maximum specific activity of 12.6 Units nits followed by Staphylococcus sciuri which showed 8.26 Units and Exiguobacterium indicum 6.81 Units

\section{Retting experiment:}

When the Pseudostems were incubated along with the endophytes in their optimized media as mentioned above for seven days good separation of the fibres was seen when Staphylococcus sciuri was used. The texture and color of the separated cellulose fibre was far better. (seeFig. I). However when pseudo stems were incubated with endophytes presence of water no separation of fibres was seen (see Fig.II)

We report that there is approx. 95\% to 98\% loss in weight in both media and water samples containing the microbes. (See TableII) Loss in weight of the pseudo-stem was calculated by the formula. Loss in weight= Initial weight- Final weight *100/ Initial weight

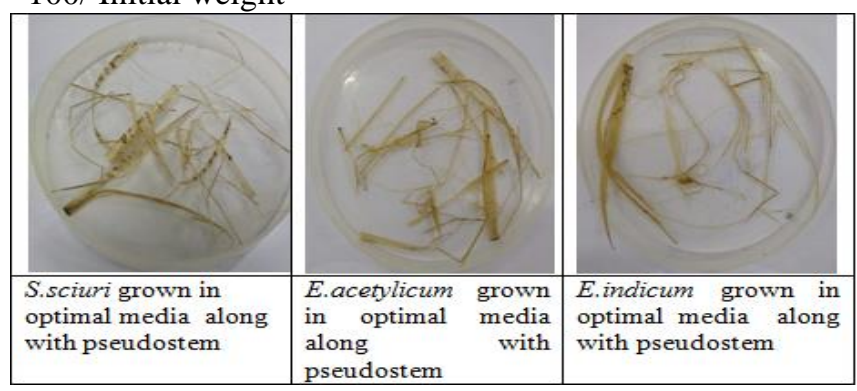

media at alkaline $\mathrm{pH}$ (8-10) for Exiguobacterium acetylicum and pectin, KNO3 media at acidic $\mathrm{pH} 4$ for Exiguobacterium indicum for seven days . Separation in the fibres is clearly seen .Coarser fibres are visible for Exiguobacterium acetylicum treated and Exiguobacterium indicum treated fibres however the fibres were more finer and smoother for Staphylococcus .sciuri treated pseudostem in optimal media

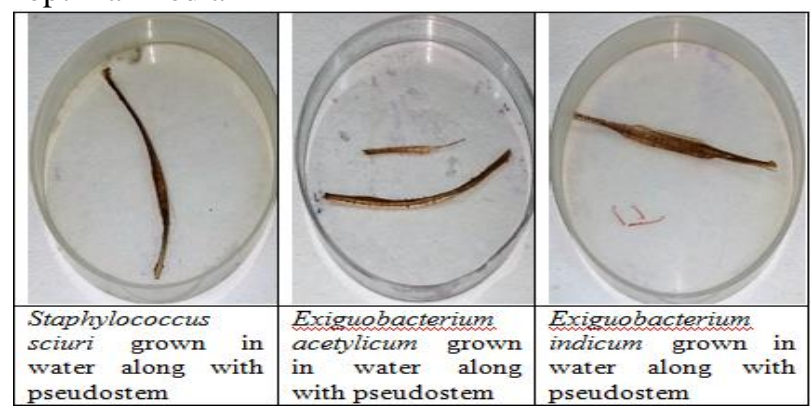

Figure II. Pseudo-stems were incubated with the endophytes in water for seven days and no separation of fibres was seen for Staphylococcus sciuri, Exiguobacterium acetylicum, or Exiguobacterium indicum treated pseudostems

Figure I Banana Pseudo stems were incubated with the identified endophytes in their optimized media: Yeast extract lactose , Tryptone media at alkaine $\mathrm{pH}$ (8-10) for Staphylococcus sciuri; Yeast extract ,pectin and KNO3

Table- II: Depicts the maximum percentage loss in weight of Banana Pseudo stem on retting. Staphylococcus sciuri being the most efficient in retting.

\begin{tabular}{|c|c|c|c|c|c|c|c|}
\hline S.No & \multicolumn{4}{|c|}{ Weight of pseudostem after 7 days of Bacterial retting in optimized media } & \multicolumn{3}{|c|}{$\begin{array}{c}\text { Weight of pseudostem after } 7 \text { days Bacterial } \\
\text { retting in distilled water }\end{array}$} \\
\hline 1 & Culture Name & $\begin{array}{c}\text { Initial } \\
\text { weight in } \\
\text { gms } \\
\end{array}$ & $\begin{array}{c}\text { Final } \\
\text { weight in } \\
\text { gms } \\
\end{array}$ & $\begin{array}{c}\text { Percentage (\%) } \\
\text { of weight loss }\end{array}$ & $\begin{array}{c}\text { Initial } \\
\text { weight in } \\
\text { gms } \\
\end{array}$ & $\begin{array}{c}\text { Final } \\
\text { weight in } \\
\text { gms } \\
\end{array}$ & $\begin{array}{c}\text { Percentage (\%) } \\
\text { of } \\
\text { weight loss } \\
\end{array}$ \\
\hline 2 & Staphylococcus sciuri & 2 & 0.04 & 98 & 2 & 0.064 & 96.8 \\
\hline 3 & $\begin{array}{c}\text { Exiguobacterium } \\
\text { acetylicum }\end{array}$ & 2 & 0.05 & 97.5 & 2 & 0.084 & 95.8 \\
\hline 4 & Exiguobacterium indicum & 2 & 0.056 & 97.2 & 2 & 0.083 & 95.85 \\
\hline
\end{tabular}

Further we also report that the bacterial strain pectinases also affect texture of fibre produced. Texture of Staphylococcus sciuri treated pseudo stems fibres was smoother and also dried faster. From our studies we propose that treatment of banana pseudostem with Staphylococcus sciuri in presence of Yeast extract lactose, Tryptone media at alkaine $\mathrm{pH}$ (8-10) for 7 days followed by drying at 37 degrees for 72 hours and mechanical separation of fibre bundles i.e mechanical combing alone produces a good textured cellulose fibres (see Fig. IIIa,III b and Table III).
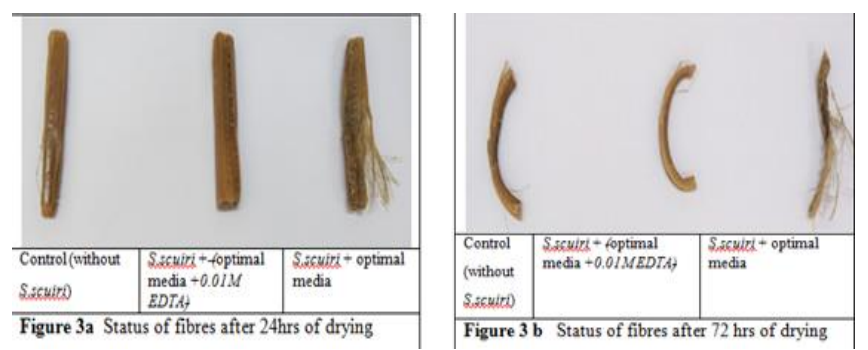


\section{Microbial Retting of Banana Pseudostem}

Figure 3 a \& b Effect of drying on texture of retted fibres : The fibres showed separation after heating and drying at 37 ${ }^{\circ} \mathrm{C}$ for 72 hrs. Retted fibres taken for the experimental studies are the ones produced when Staphylococcus scuiri was used to treat banana pseudostem in its optimized media. The control here are the fibres where S.scuiri is not used, Second set depicts the effect on fibres when treated with enzyme produced from Staphylococcus scuiri in presence of $0.01 \mathrm{M}$ EDTA and third set of experiment is when pseudostem is treated Staphylococcus scuiri without presence of EDTA in the optimized media. As seen in the figure the fibres can be easily separated on drying if they are incubated with Staphylococcus scuiri which is grown in presence of optimal media without EDTA. Requirement for drying temperatures and time are also very low which is 37 ${ }^{\circ} \mathrm{C}$ for 72 hrs see fig $3 b$.

Table3 Effect of treatment on weight loss of Pseudo-stem

\begin{tabular}{|c|c|c|c|c|c|}
\hline $\begin{array}{l}\text { S. } \\
\text { No }\end{array}$ & $\begin{array}{c}\text { Type of } \\
\text { treatment for } \\
\text { Pseudostem }\end{array}$ & $\begin{array}{c}\text { Initial } \\
\text { weight }\end{array}$ & $\begin{array}{c}\text { Weight } \\
\text { after } \\
24 \\
\text { hrs.of } \\
\text { drying }\end{array}$ & $\begin{array}{c}\text { Weight } \\
\text { after } \\
72 \text { hrs. } \\
\text { of } \\
\text { drying }\end{array}$ & $\begin{array}{c}\text { Percentage } \\
\text { (\%) of } \\
\text { weight } \\
\text { loss }\end{array}$ \\
\hline 2 & $\begin{array}{c}\text { Control( } \\
\text { without } \\
\text { Staphylococcus } \\
\text { scuiri) }\end{array}$ & 2.87 & 0.277 & 0.234 & 91 \\
\hline 3 & $\begin{array}{c}\text { Staphylococcus } \\
\text { scuiri + } \\
\text { optimal media } \\
\text { +0.01M } \\
\text { EDTA) }\end{array}$ & 3.48 & 0.219 & 0.172 & 94 \\
\hline $\begin{array}{c}\text { Staphylococcus } \\
\text { scuiri + } \\
\text { optimal media }\end{array}$ & 3.66 & 0.198 & 0.12 & 96.7 \\
\hline
\end{tabular}

\section{DISCUSSION}

Banana fibre because of its fineness, spinnability and light in weight, is preferred by the textile industry. It has low elongation value and strong moisture absorption property also permits dyebality thus enzymatically treated banana fibre has high potential to become a sustainable raw material for textile industry.Microbial pectinases account for $25 \%$ of the global enzymes sales. Microbial pectinases have found application in production of natural fibres during retting which is fast replacing other methods like mechanical extraction of fibres, chemical methods to remove the gummy material from fibres which reduce the fibre quality , density, and strength [11],[12]. Use of crude enzyme formulations is preferred over purified enzymes during retting as the cost of retting process is lowered. For further reduction in cost of production of enzymes researchers have used inexpensive substrates like konjanc flour, wheat bran [13],[14]

\section{CONCLUSION}

We report a biological ecofriendly method of microbial retting method where pectinases produced by the endophytic microorganisms isolated from corm of Amorphophallus paeoniifolius caused $95 \%$ to $98 \%$ loss in weight of banana pseudostems in both media and water. The texture, color and separation of fibre bundles of cellulose was far better when Staphylococcus sciuri was used for retting in its optimized media conditions. Other pectinase producing endophytic bacteria isolated by us are Exiguobacterium acetylicum, Exiguobacterium indicum

\section{ACKNOWLEDGMENT}

The authors are delighted to acknowledge Jaypee Institute of Information Technology Noida, Uttar pradesh India for their cooperation during this study.

\section{CONFLICT OF INTEREST}

There are no conflicts of interest between the authors

\section{REFERENCES}

1. G. H. A. K. Mohantya, b, M. Misraa, 2000, "Biofibres, biodegradable polymers and biocomposites: An,” Macromol. Mater. Eng., vol. 276, no. 1, pp. 1-24.

2. P. Gañán, R. Zuluaga, J. M. Velez, and I. Mondragon, 2004 "Biological natural retting for determining the hierarchical structuration of banana fibres," Macromol. Biosci., vol. 4, no. 10, pp. 978-983.

3. S. R. Chiliveri, S. Koti, and V. R. Linga,2016 "Retting and degumming of natural fibres by pectinolytic enzymes produced from Bacillus tequilensis SV11-UV37 using solid state fermentation," Springer plus, vol. 5 , no. 1 .

4. D. R. Kashyap, P. K. Vohra, S. Chopra, and R. Tewari, 2001 "Applications of pectinases in the commercial sector: A review," Bioresour. Technol., vol. 77, no. 3, pp. 215-227.

5. Priya V and Sashi V 2014.Pectinase Enzyme Producing Microorganisms. International Journal of Scientific and Research Publications,4(3), pp 1-4

6. E. Namasivayam, D. John Ravindar, K. Mariappan, A. jiji, M. Kumar, and R. L. Jayaraj, 2011 "Production of extracellular pectinase by Bacillus cereus isolated from market solid waste," J. Bioanal. Biomed., vol. 3, no. 3, pp. 70-75.

7. Oumer OJ and Abate D 2018. Screening and Molecular Identification of Pectinase Producing Microbes from Coffee Pulp. BioMed Research International https://doi.org/10.1155/2018/2961767

8. M. M. BRADFORD, , 1976. "A Rapid and Sensitive Method for the Quantitation Microgram Quantities of Protein Utilizing the Principle," Anal. Biochem., vol. 72, pp. 248-254

9. Di Candilo, M., Bonatti, P.M., Guidetti, C., Focher, B., Grippo, C., Tamburini, E. and Mastromei, G., 2010. Effects of selected pectinolytic bacterial strains on water-retting of hemp and fibre properties. Journal of applied microbiology, 108(1), pp.194-203.

10. Yadav, S., Maurya, S.K., Anand, G., Dwivedi, R. and Yadav, D., 2017 Purification, characterization and retting of Crotolaria juncea fibres by an alkaline pectin lyase from Fusarium oxysporum MTCC 1755. 3 Biotech, 7(2), p.136.

11. Anand, G., Yadav, S. and Yadav, D., 2016. Purification and characterization of polygalacturonase from Aspergillus fumigatus MTCC 2584 and elucidating its application in retting of Crotalaria juncea fibre. 3 Biotech, 6(2), pp.1-7.

12. Chiliveri, S.R., Koti, S. and Linga, V.R., 2016. Retting and degumming of natural fibres by pectinolytic enzymes produced from Bacillus $\begin{array}{llll}\text { tequilensis } & \text { SV11-UV37 using solid } & \text { state }\end{array}$ fermentation. SpringerPlus, 5(1), pp.1-17.

13. Zhao, D., Liu, P., Pan, C., Du, R., Ping, W. and Ge, J., 2017. Flax retting by degumming composite enzyme produced by Bacillus licheniformis HDYM-04 and effect on fibre properties. The Journal of The Textile Institute, 108(4), pp.507-510.

14. Garg, G., Singh, A., Kaur, A., Singh, R., Kaur, J. and Mahajan, R., 2016. Microbial pectinases: an ecofriendly tool of nature for industries. 3 Biotech, 6(1), pp.1-13.

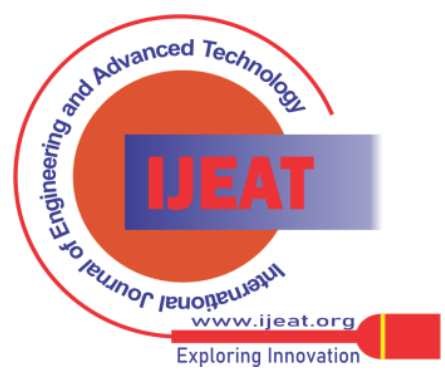




\section{AUTHORS PROFILE}

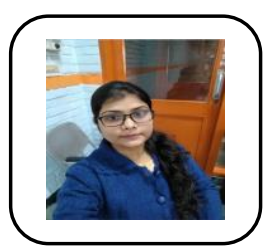

Sonia Sharma, She is a Ph.D scholar in Department of Biotechnology at Jaypee Institute of Information Technology. She has done her MSc. In Applied microbiology and Biotechnology from Bansthali university.

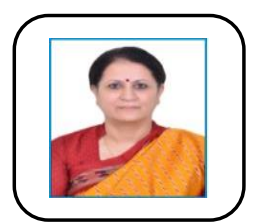

Prof. Neeraj Wadhwa, Professor joined the Department of Biotechnology at 2002. She graduated in Zoology (Honours) from Fergusson College, University of Pune, and Masters in Zoology from Pune University. She did her PhD in 1995 from University of Delhi, where her research focus was to study the post-transcriptional and post-translational modification in Plant Gene Expression

Published By:

Blue Eyes Intelligence Engineering and Sciences Publication (BEIESP)

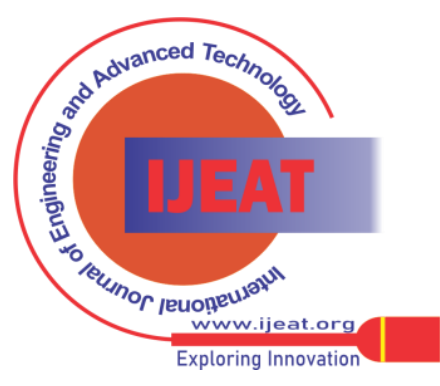

